\title{
Karakteristik Tafsir al-Mushaf al-Mufassar karya Farid Wajdi
}

\author{
Wahyu Kusuma Aji* \\ UIN Sunan Kalijaga, Yogyakarta, Indonesia \\ Email: wahyupenceng212@gmail.com
}

\begin{abstract}
This study aims to reveal the characteristics of the book al-Mushafal-Mufassar by Muhammad Farid Wajdi, an Egyptian-born mufasir figure. In addition, the reasons for using these characters are also discussed. This research is a qualitative research and applies literature study. After going through the research process, The author finds several things about the characteristics of al-Mushaf al-Mufassar.First, the character of alMushaf al-Mufassar is reflected in two aspects: (1) a simple and straightforward posture of interpretation with a textual-lugawi style that is packaged ijmali. The posture his simple and straightforward interpretation can be identified in every discussion the interpretation is always presented in one complete page, nothing more. In addition, the writing layout and presentation of the interpretation are more oriented towards convenience and comfort for the reader, namely the proportional placement of the verse text to be interpreted, tafsir al-alfaz and tafsir al-ma'ani: the verse text is presented in mushafi, while tafsir al-alfaz is placed right on the side as hawamisy, while tafsir al-ma'ani is placed at the bottom as an interpretation of the verse meaning globally; (2) simple structure and style of interpretation language. The language of interpretation is straightforward and practical. Moreover, they often use the linguistic structure of the Koran itself. Second, The use of posture characters and simple and straightforward interpretive language, on the one hand can be said to be a criticism of the previous tradition of interpretation, and on the other hand as part of the strategy of M. Farid Wajdi in the context of competition in the "interpretive consumption market" in Egypt..
\end{abstract}

Keywords: al-Mushaf al-Mufassar; Characteristics of Interpretation; Farid Wajdi.

\begin{abstract}
Abstrak
Penelitian ini bertujuan untuk mengungkap karakteristik kitab al-Mushaf al-Mufassar karya Muhammad Farid Wajdi seorang tokoh mufasir kelahiran Mesir. Selain itu diulas pula alasan dari penggunaan karakter tersebut. penelitian ini merupakan penelitian kualitatif dan menerapkan studi kepustakaan. Setelah melewati proses penelitian, penulis menemukan beberapa hal mengenai karakteristik al-Mushaf alMufassar Pertama, karakter al-Mushafal-Mufassar tercermin pada dua aspek: (1) postur tafsir yang simpel dan lugas dengan corak tekstual-lugawi yang dikemas secara ijmali. Postur tafsirnya yang simpel dan lugas tersebut dapat ditengarai pada setiap bahasan tafsirnya selalu disajikan dalam satu halaman tuntas, tidak lebih. Selain itu, layout penulisan dan penyajian tafsirnya pun lebih berorientasi pada kemudahan dan kenyamanan bagi pembaca, yakni adanya penempatan secara proporsional antara teks ayat yang hendak ditafsirkan, tafsir al-alfaz dan tafsir al-ma'ani: teks ayat disajikan secara mushafi, sementara tafsir al-alfaz ditempatkan persis di bagian samping sebagai hawamisy, sedangkan tafsir al-ma'ani ditempatkan di bagian bawah sebagai tafsiran makna ayat secara global; (2) struktur dan gaya bahasa tafsir yang sederhana. Bahasa tafsir yang lugas, tidak bertele-tele. Bahkan kerap menggunakan struktur kebahasaan Al-Qur'an itu sendiri.Kedua, penggunaan karakter postur dan bahasa tafsir yang simpel dan lugas tersebut, di satu sisi bisa dikatakan sebagai kritik atas tradisi tafsir sebelum-sebelumnya, dan di sisi lain sebagai bagian dari strategi M. Farid Wajdi dalam konteks persaingan "pasar konsumsi tafsir" di Mesir.
\end{abstract}

Kata Kunci: al-Mushaf al-Mufassar; Farid Wajdi; Karakteristik Tafsir.

\section{PENDAHULUAN}

Sebagai sumber ajaran, Al-Qur'an telah melahirkan sederet teks turunan (Abdullah, 2003). Teks yang berperan dan berfungsi sebagai penjelas atas makna, hukum, hikmah, nilai dan prinsip yang

*Corresponding Author

Received: December 21, 2020; Revised: January 23, 2021; Accepted: February 02, 2021 
Khazanah Theologia, Vol. 3 No. 1 (2021): 35-54

Karakteristik Tafsir al-Mushaf al-Mufassar karya Farid Wajdi

Wahyu Kusuma Aji

dikandungnya. Teks turunan tersebut jumlahnya sangat banyak dengan corak yang beragam. Misalnya kitab Jami' al-Bayan fi Tafsir Al-Qur'an al-Karim karya Ibnu Jarir al-Tabari (w.310 H) atau lebih dikenal dengan Tafsir al-Tabari. Sebuah kitab tafsir yang menurut Jumhur sangat kuat dalam penggunaan riwayatriwayat sebagai sumber penafsirannya (al-tafsir bi al-ma'sur). Selain Tafsir al- Tabari, karya-karya tafsir bi al-ma'sur lainnya adalah Ma'alim al-Tanzil karya al-Bagawi (w.516 H), Tafsir Al-Qur'an al-'Azim karya Ibnu Kasir (w.774 H), Al-Durru al-Mansur fi Tafsir bi al-Ma'sur karya al-Suyuti (w. 911 H) dan lain sebagainya.

Berbeda dengan kitab Mafatih al-Gayb karya al-Razi (w. 606 H). Kitab ini dinilai cenderung dominan dalam penggunaan nalar sebagai pijakan penafsirannya (al-tafsir bi al-ra'y). Selain Tafsir al-Razi, karyakarya tafsir bi al-ra'y lainnya adalah Anwar al-Tanzil wa Asrar al-Ta'wil karya Baidawi (w. 691 H), Lubab al-Ta'wil fi Ma'an al-Tanzil karya al-Khazin (w. 741 H), Mudarik al-Tanzil wa Haqa'iq al-Ta'wil karya alNasafi (w. 791 H), dan lain sebagainya.

Dari sekian banyak karya tafsir, ada satu karya tafsir yang ditulis oleh sastrawan asal Mesir, Muhammad Farid Wajdi (1868-1933), yakni al-Mushafal-Mufassar. Kitab ini ditulis secara ringkas dengan bahasa yang lugas. Sayangnya, karya tafsir ini-tampak-luput dari perhatian para pengkaji tafsir AlQur'an, khususnya di bidang studi kitab tafsir. Setidaknya, asumsi ini didasarkan pada minimnya (untuk tidak mengatakan tidak ada) penelitian yang membahas tafsir tersebut. Sekalipun ada ulasan mengenai karya tersebut, namun sifatnya hanya 'menyinggung sekilas' sebagaimana ulasan Mani' Abd al-Halim Mahmud dalam salah satu bukunya, Manahij al-Mufassirin (Mahmud, 2000). Analisis sederhana mengenai metode penafsiran Muhammad Farid Wajdi juga disampaikan oleh Al-Bayyumi (1993). Hasil analisis Albayyumi menemukan bahwa metode yang dilakukan adalah dengan menjelaskan arti kata-kata kemudian menguraikan arti secara global, dan menurutnya,metode ini',lebih tepat bagi. para pembaca kalangan Arab, dan lebih mudah bagi yang membaca Al-Qur'an terjemahan.

Padahal jika ditinjau dari logika periodisasi, al-Mushaf al-Mufassar adalah karya yang muncul di abad 19/20-an. Mestinya kalangan pengkaji tafsir-terutama para pengkaji yang hidup di abad 20/21an-memasukkan karya tersebut sebagai salah satu objek material kajian tafsirnya. Sebut saja Ignaz Goldziher melalui Mazahibut Tafsir-nya, ia tidak memasukkan al-Mushaf al-Mufassar sebagai salah satu objek material kitab tafsir di era 19/20-an yang dikajinya (Goldziher, 2015). Bahkan dalam beberapa karya tentang "Studi Kitab Tafsir" yang terbit di abad 20/21-an pun tidak diketemukan al-Mushaf alMufassar sebagai salah satu objek kitab tafsir yang dikaji, misalnya Membahas Kitab Tafsir Klasik-Modern karya Faizah Ali Syibromalisi dan Jauhar Aziz. Ada pula Dzikri Nirwana lewat Peta Tafsir di Mesir: Melacak Perkembangan Tafsir Al-Qur'an dari Abad Klasik hingga Modern, ia pun tidak memasukkan karya M. Farid Wajdi ke dalam bahasan tafsirnya (Nirwana, 2010).

Ada dua asumsi yang dapat dijadikan sebagai dalil hipotetif mengenai minimnya perhatian terhadap al-Mushaf al-Mufassar. Pertama, Muhammad Farid Wajdi lebih dikenal sebagai sastrawan dan tokoh pembaharu Islam dari segi sosio-politik dibandingkan dirinya sebagai mufassir. Hal ini tidak lepas dari perjalanan intelektual dan karirnya yang banyak bergelut di bidang sastra dan politik. Karyakaryanya pun didominasi oleh wacana kesusastraan dan peradaban seperti Da'irah Ma'arif al-Qarn al'Isyrin, Al-Islam fi al-'Asr al-IImi, Naqd Kitab al-Syi'r al-Jahili dan sebagainya. Kedua, Muhammad Farid Wajdi adalah tokoh yang hidup pada masa antara abad 19 akhir dan awal abad 20-an. Tepatnya ia lahir pada 1875 dan meninggal dunia pada 1954 (Al-Rafi'i, t.th.). Dalam catatan sejarah Mesir, pada masa tersebut hidup pula duo pembaharu pengarang tafsir al-Manar: Muhammad 'Abduh (1849-1905) dan Rasyid Rida (1865-1935). Sehingga karya tafsir Farid Wajdi tertutup oleh popularitas kitab tafsir al-Manar yang muncul lebih dulu. Terlebih bahwa kitab al-Manar bermula dari forum kuliah tafsir yang dipimpin oleh Muhammad 'Abduh (Shihab, 1994). Selanjutnya dibuatlah majalah atau tabloid al-Manar guna 
Khazanah Theologia, Vol. 3 No. 1 (2021): 35-54

Karakteristik Tafsir al-Mushaf al-Mufassar karya Farid Wajdi

Wahyu Kusuma Aji

memperluas kajian pemahaman seputar isi al-Qur'an ke seluruh masyarakat. Hal ini sangat mungkin menjadikan al-Manar dan pengarangnya sangatlah terkenal, dan dapat berakibat tertutupnya nama Muhammad Farid Wajdi dalam bidang tafsir Al-Qur'an di tanah Mesir atau bahkan penjuru dunia.

\section{METODE PENELITTIAN}

Penelitian ini berjenis kualitatif dengan menggunakan sumber kepustakaan. Sumber-sumber data yang digunakan dalam penelitian ini diklasifikasikan menjadi dua bagian. Pertama, Sumber Primer, yakni melakukan proses penelitian dengan merujuk langsung karya tafsir Muhammad Farid Wajdi berupa kitab al-Mushafal-Mufassar. Kedua, Sumber Sekunder, adalah dengan menggunakan literatur, artikel dan jurnal yang terkait dengan studi kitab tafsir.

Fokus pembahasan dalam penelitian ini adalah persoalan karakteristik (teknis,gaya bahasa, sistematika, metode, sumber dan corak) tafsir Farid Wajdi yang menggunakan dua domain, yakni eksternal dan internal (Gusmian, 2015), maka metode yang ditempuh adalah, pertama, metode deskriptifanalisis. Metode ini dilakukan untuk mengulas wilayah 'bagaimana' teknis dan sistematika penyusunan, metode, sumber dan corak penafsirannya; kedua, metode hermeneutik berdasarkan hubungan triadik antara teks-pengarang-pembaca (Nugroho, 2016). Metode ini ditujukan untuk mengulas wilayah 'mengapa' M. Farid Wajdi menggunakan teknis dan sistematika penyusunan tafsirnya seperti itu. untuk mengetahui hal tersebut tidaklah mungkin hanya mencukupkan pada analisis permukaan teks, melainkan dibutuhkan analisis tentang relasi antara tafsir tersebut dengan konteks masyarakat saat itu.

\section{HASIL DAN PEMBAHASAN}

\section{Riwayat Hidup Farid Wajdi}

Muhammad Farid bin Mustafa Wajdi bin 'Ali Rasyad (Wajdi, 1971) lahir pada tahun 1875 di Kota Iskandariyah (Al-Bayumi, 2003), yang sekarang dikenal dengan Kota Alexandria, Mesir. Kota kelahirannya ini merupakan pusat ekspor dan impor di Mesir. Ayahnya, Mustafa Wajdi adalah pejabat Iskandariyah. sewaktu kecil ia belajar membaca dan menulis di kelas awal pada salah satu sekolahan dekat pelabuhan Iskandariyah.

Karena urusan pekerjaan ayahnya, M. Farid Wajdi sekeluarga pindah ke Kairo. Ayahnya memasukkannya di sekolahan yang khusus dalam bidang bahasa Inggris. Ketidak cocokan M. Farid Wajdi dengan metode pembelajaran di sana menjadikannya tidak puas. Sehingga ia meminta izin ayahnya untuk mencari ilmu tanpa harus sekolah. Sang ayah mengizinkannya karena menghormati pendapat anaknya, dan ayahnya faham bahwa anaknya mampu menguasai bahasa Prancis dan Arab dengan membaca bermacam-macam buku, majalah dan koran bahasa Prancis dan Arab (Al-Bayumi, 2003). Hal ini membuat ayahnya yakin kalau anaknya mampu menguasai bahasa Inggris secara autodidak.

Ketika umurnya enam belas tahun ia masuk sekolah Tahdiriyyah (persiapan). Baru beberapa bulan sekolah, ayahnya diangkat sebagai wakil gubernur Dimyat. Hal ini membuat dirinya sekeluarga pindah ke kota yang terkenal dengan kesantunan dan kedalaman agama penduduknya (Mahmud, 2000). Melihat ayahnya yang menjadi orang ke dua di daerah Dimyat, M. Farid Wajdi selalu berpesan kepada ayahnya agar tidak mengikuti hawa nafsu. Hal ini tidak pernah menjadikan ayahnya marah, bahkan menjadikan bangga kepada akhlak putranya.

Di Dimyat ini M. Farid Wajdi sering menghadiri pengajian mingguan yang diisi oleh ulama' besar Dimyat. Akan tetapi ayahnya selalu mengingatkannya untuk berhati-hati setiap bertanya selain itu 
Khazanah Theologia, Vol. 3 No. 1 (2021): 35-54

Karakteristik Tafsir al-Mushaf al-Mufassar karya Farid Wajdi

Wahyu Kusuma Aji

melarang anaknya untuk menyangkal pendapat ulama-ulama disitu (Al-Bayumi, 2003). Semisal ingin menghadiri maka cukup mendengarkan. Hal ini ayahnya lakukan untuk menghindari perselisihan. Selain itu ayahnya tahu bahwa M. Farid Wajdi sosok yang kritis dan tidak pernah puas dengan jawaban ulama'ulama' tersebut atas pertanyaannya.

Kondisi-kondisi di atas membuat M. Farid Wajdi ragu terhadap permasalahan agama terutama akidah yang dia rasa masih samar-samar. Untuk memecahkannya ia mencoba mengikuti pengajian yang biasa diikuti ayahnya, tapi sama sekali tidak membantu (Al-Bayumi, 2003). Ia kemudian bergerak menimba ilmu kepada ulama'-ulama' besar yang hidup di zamannya, namun lagi-lagi, ia tidak menemukan sesuatu yang dapat memuaskan hasrat kengintahuannya. Kemudian dia berniat untuk menguasai dan memperdalam seluruh jenis buku. Caranya adalah dengan pindah dari satu buku ke buku yang lain. Setelah memperdalam buku tentang alam, ia pindah ke buku tentang ilmu sosial, psikologi, sejarah dan terakhir, buku agama. Hingga akhirnya ia dapat menemukan hakikat tentang keagungan dan derajat Islam yang selama ini ia cari. Ia semakin yakin akan kesesuaian ajarannya dengan undang-undang logika buatan manusia. Menurutnya, ajaran Islam sesuai dengan akal sehat manusia. Kaidah dan prinsip-prinsip ajaran Islam mengajarkan fondasi terkuat tentang keistimewaan yang dapat membuat seorang manusia menuju puncak kemuliaan dan perbaikan alam. Jadi, bagaimana mungkin kita berusaha keras untuk berpegang teguh pada kejumudan yang hanya akan membunuh kita? Kejumudan yang tanpa di topang dengan ilmu adalah sebuah kesesatan belaka. Kita harus memiliki benteng terbaik agar dapat mengungkap bercokolnya kebatilan pada kebenaran yang telah jelas (Al-Bayumi, 2003). Terlewatinya masa-masa skeptis tersebut menjadikan pikirannya merdeka serta pemahaman agama yang kukuh.

\section{Latar Belakang Penulisan}

Kitab al-Mushaf al-Mufassar memiliki nama lain yaitu Safwat al-Irfan fi Tafsir al-Qur'an yang ditulis seorang diri oleh M. Farid Wajdi. Kitab ini selesai ditulis pada tahun 1368 H/1948 M. (Al-Bayumi, 2003). Kitab ini sudah diterbitkan oleh Dar al-Sya'bi berkali-kali hingga mendekati 100.000 naskah (Wajdi, t.th.). Meskipun sudah dicetak berulang kali, namun kitab ini tidak begitu populer bagi kalangan pengkaji tafsir. Hal ini ditandai dengan jarangnya para peneliti yang mengkaji kitab ini.

Terlepas dari hal tersebut, terkait latar belakang dan motivasi penulisan kitab al-Mushaf alMufassar, M. Farid Wajdi mengungkapkan dalam mukadimah tafsirnya sebagai berikut (Wajdi, t.th.):

Bertepatan pada tahun $1323 \mathrm{H}$. aku mencoba untuk membaca Al-Qur'an dengan merenungi dan memahami isinya sebagaiman ketika Allah mewahyukannya kepada Nabi Muhammad. Ketika itu, aku merasa kesulitan untuk menemukan kitab-kitab tafsir yang sesuai harapanku baik dari metode yang sederhana dan bersahaja. Kitab-kitab tafsir yang tebal menghabiskan banyak waktu untuk membacanya, apalagi pada waktu bersamaan orang-orang disibukkan dengan cabang ilmu yang beragam. Sedangkan kitab-kitab yang ringkas didalamnya banyak melepaskan permaslahanpermasalahan dalam disiplin tafsir. Adapun yang aku kehendaki itu adalah tafsir yang memberikan penjelasan kosa kata arab secara hakiki. Kemudian menampilkan tafsir ma'na dengan ungkapan yang terlepas dari permasalahan-permasalahan yang sifatnya teknis, disertai penjelasan asbab alnuzul ayat, supaya pembaca merasa faham dan jelas terhadap kemuliaan ayat Al-Qur'an. Aku meletakkan penafsiran secara terpisah dengan ayat. Dan menjelaskannya pada hamisy (catatan pinggir) mushaf. Hal ini supaya dapat memudahkanku ketika membaca Al-Qur'an al-Karim.

Sebelum aku melakukan penafsiran, aku mengerti bahwa pekerjaan ini mengharuskanku untuk menyelesaikan pengamatan terhadap Al-Qur'an terlebih dahulu. Setelah itu aku aku mengerjakannya hingga selesai dan menyebarluaskannya ke khalayak umum. Inilah kitab tafsir yang aku persembahkan kepada pembaca,aku berharap amal ini dapat menjadi sebab dan lantaran 
Khazanah Theologia, Vol. 3 No. 1 (2021): 35-54

Karakteristik Tafsir al-Mushaf al-Mufassar karya Farid Wajdi

Wahyu Kusuma Aji

tersebarnya kandungan ma'na Kitab Allah kepada manusia yang belum mewujudkannya untuk pencapaian tujuan hidup mereka yang sesuai dengan Al-Qur'an."

Dari pernyataan M. Farid Wajdi di atas dapat di pahami, bahwa motivasinya untuk menulis kitab tafsir al-Mushafal-Mufassar ini karena kurang puasnya ia dengan produk-produk tafsir sebelumnya. Selain itu ia juga berharap, dengan menulis kitab tafsir ini dapat bermanfa'at untuk syiar mengenai isi kandungan Al-Qur'an kepada seluruh umat manusia.

Kitab al-Mushaf al-Mufassar yang menjadi rujukan utama penelitian ini diterbitakan oleh penerbit dar al-sya'b tanpa tahun terbit. Kitab ini berukuran 27,5 x 19,5cm dan berjumlah 1 jilid dengan ketebalan $3,5 \mathrm{~cm}$ berisi 827 halaman.

\section{Teknik dan Sistematika Penulisan}

Kitab al-Mushaf al-Mufassar adalah karya M. Farid Wajdi di bidang tafsir. Sebagai sebuah kitab, alMushaf al-Mufassar memiliki karakter khas dalam teknis dan sistematika penyusunannya. Adapun karakter tersebut meliputi poin-poin berikut ini:

1. Sistematika penyusunan al-Mushaf al-Mufassar mengikuti pola tartib mushafi, bukan tartib nuzuli. Artinya, M. Farid Wajdi memulai tafsirnya dari penafsiran surah-surah yang urutannya sesuai dengan mushaf standar. Dimulai dari surah al-Fatihah, al-Baqarah, Ali 'Imran, al-Nisa' dan seterusnya hingga surah al-Nas.

2. Sistematika konten kitab secara keseluruhan, susunannya meliputi: halaman depan atau cover, kata pengantar, penafsiran dan daftar isi.

3. Al-Mushaf al-Mufassar disusun dengan pola page orientation dari kanan ke kiri (right-to-left) sebagaimana yang lazim dalam layout teks Arab.

4. Terdapat keterangan: (1) nomor halaman (page number) yang penulisannya terletak di pojok kanan atas (top-right) untuk lembar halaman kanan dan di pojok kiri atas (top-letf) untuk lembar halaman kiri; (2) urutan juz yang penulisannya terletak di bagian tengah atas pada lembar halaman kanan; dan (3) nama surah yang penulisannya terletak di bagian tengah atas (top-center) pada lembar halaman kiri. Semua keterangan tersebut ditulis dengan aksara Arab.

5. Menggunakan tanda kurung " 0 " untuk beberapa konteks:

a) Potongan lafal ayat yang hendak dijelaskan maknanya. Misalnya ketika M. Farid Wajdi menafsirkan kata al-Kitab dalam potongan Q.S. Al-Baqarah [2]: 2 (Wajdi, t.th.), ia meletakkan kata tersebut di dalam tanda kurung. Setelah itu ia memaparkan penafsirannya terhadap kata tersebut.

b) Keterangan yang statusnya sebagai penegas atas penafsiran. Misalnya dalam penafsiran Q.S. AlBaqarah [2]: 41, wa aminu... (Wajdi, t.th.). yang berarti berimanlah kalian. M. Farid Wajdi menegaskan potongan ayat tersebut dengan memberi tanda kurung yang yang isi teksnya: alkalamu li bani Israil, yakni khitab yang terkandung pada] kalam ini ditujukan pada bani Israil.

c) Keterangan asbab al-nuzul sebagai penguat penafsiran, seperti dalam penafsiran Q.S. Al-Duha [93]: wa al-dluha, wa al-laili idza saja... (Wajdi, t.th.), M. Farid Wajdi memberikan catatan yang diberi tanda kurung. Catatan tersebut merupakan keterangan asbab al-nuzul yang isinya berbicara tentang jawaban atas kalangan musyrik yang menganggap Tuhan telah membenci dan meninggalkan Muhammad lantaran ia tidak lagi menerima wahyu untuk beberapa waktu.

d) Ayat Al-Qur'an yang dijadikan sumber atau landasan penafsiran suatu ayat yang sedang ditafsirkan. Misalnya ketika M. Farid Wajdi menafsirkan Q.S. Yasin [36]: 7 (Wajdi, t.th.), ia menafsirkan ayat tersebut dengan Q.S. Al-Sajdah [32]: 13 yang ia tuliskan dalam tanda kurung. 


\section{Sumber Penafsiran}

Sumber penafsiran di sini adalah acuan dasar sebagai tempat mufasir menggali bahan-bahan untuk bangunan penafsirannya. untuk melakukan hal ini, biasanya seorang mufasir menggunakan teks dasar Islam (Al-Qur'an, Hadis dan asar) dan teks atau acuan lain seperti Israiliyyat, sya'ir, ilmu-ilmu keislaman, ilmu bahasa, penemuan-penemuan di bidang sosial ataupun pendapat para ulama' dengan berbagai kecendrungannya (Mansur, 2004).

Sedangkan M. Farid Wajdi sendiri, didalam menyusun kitab tafsir al-Mushaf al-Mufasar tidak lepas dari acuan diatas meskipun hanya sebagian. Hal ini berdasarkan pengamatan penulis, bahwa dalam penafsirannya, M. Farid Wajdi menggunakan sumber acuan seperti Al-Qur'an, Hadis, Asar serta pendapatpendapat 'ulama.

\section{Al-Qur'an}

Penggunaan ayat sebagai sumber penafsiran ditempuh M. Farid Wajdi dalam menyusun tafsirnya. Sebagaimana penafsirannya pada konteks tafsir al-alfaz terhadap kata la mubaddila li kalimatih dalam Q.S. Al-An'am [6]: 115. Kata tersebut ia jelaskan sebagai berikut:

$$
\begin{aligned}
& \text { (لا مبدل لكلماته) أى لا محرف لها. وهذا وعد اخر بأن القرأن لا يستطيع أن يحرفه أحد إلى جانب } \\
& \text { قوله تعالى إنا نحن نزلنا الذكر و إنا له لحافظوون. }
\end{aligned}
$$

(tidak ada yang dapat mengganti kalimatnya) yakni tidak ada yang mengubah firmannya. Ini merupakan Janji bahwasannya tidak ada seorangpun yang mampu mengubah redaksi AlQur'an.sebagaimana firman Allah, sesungguhnya akulah yang menurunkan Al-Qur'an, dan akulah yang menjaganya.

Berdasarkan contoh tersebut tampak bahwa M. Farid Wajdi menggunakan Q.S. Al-Hijr [15]: 9: inna nahnu nazzalna al-zikra wa inna lahu lahafizun sebagai landasan sumber penafsiran kata la mubaddila li kalimatih dalam Q.S. Al-An'am [6]:115.

\section{Hadis Nabi}

Pada konteks tafsir al-alfaz misalnya ketika ia menafsirkan kata jannatu 'adn dalam Q.S. AlTaubah[9]: 72, kata tersebut ia jelaskan sebagai berikut.

$$
\text { (جنات عدن ) عن النبى صلى الله عليه وسلم : عدن دار الله التى لم ترها عين قط ولم تخطر على قلب }
$$

(Surga 'adn) berdasarkan hadis Nabi saw.: surga 'and adalah rumah Allah yang tidak dapat dilihat oleh mata manusia dan dirabaoleh pikiran manusia. Didalamnya tidak tinggal selain para Nabi, Sahabat dan Syuhada'.

Berdasarkan contoh tersebut tampak bahwa M. Farid Wajdi menggunakan sumber hadis Nabi menafsirkan kata jannatu 'adn. Namun ia tidak menampilkan kualitas dari sumber hadis yang ia jadi rujukan tersebut. 
Khazanah Theologia, Vol. 3 No. 1 (2021): 35-54

Karakteristik Tafsir al-Mushaf al-Mufassar karya Farid Wajdi

Wahyu Kusuma Aji

\section{Asar al-Sahabi}

Pada konteks tafsir al-ma'ani misalnya ketika ia menggunakan asar sahabat untuk menafsirkan $Q$. S. Al-Baqarah [2]: 158, sebagaimana penjelasannya dibawah ini:

$$
\text { قال عاصم بن سليمان: سألت أنسا عن الصفا والمروة، قال كنا نرى أفما من أمور الجاهلية فلما جاء }
$$

'Asim bin Sulaiman berkata: aku bertanya kepada Anas terkait Safa dan Marwa, Anas menjawab, Safa Marwa awalnya merupakan tradisi Jahiliah. Ketika Islam datang keduanya tetap dipertahankan. Kemudian Allah berfirman: Sesungguhnya Safa dan Marwa merupakan tandatanda dari Allah.

Pada contoh di atas nampak bahwasannya sumber penafsirannya terhadap Q. S. Al-Baqarah [2]: 158 didasarkan perkataan 'Asim bin Sulaiman yang merupakan salah satu sahabat Nabi Muhammad.

\section{Pendapat Ulama}

Sebagaimana ia katakan dalam mukadimah tafsirnya, M. Farid Wajdi menggunakan pendapat ulama sebagai bahan rujukan tafsirnya, terutama pendapat-pendapat yang telah disepakati kalangan mufassir:

$$
\begin{aligned}
& \text { هنا يجب على أن أنبه الى أنى استخلصت هذا التفسير من الأراء المجمع عليها لدى أئمة المفسرين، } \\
& \text { وأقطات أهل السنة، فلم أخرج به عن سننهم قيد شعرة ليوافق مذهبا من المذاهب، أو يؤيد رأيا من } \\
& \text { الأراء الفردية ولو اضطرانى الكلام فن بعض الأيات على أن أورد رأيا لى أو لأحد من غير أهل السنة ، } \\
& \text { نبهت إليه وعزوته لقائله حتى يكون القارئ على بينة من أمره. }
\end{aligned}
$$

Pada tulisan ini seharusnya saya mengungkapkan bahwa dalam tafsir ini banyak berasal dari ahliahli tafsir terdahulu. Aku juga membubuhkan pendapat-pendapat Ahli Sunnah. Namun aku tidak memperkuat salah satu pendapat dari ragam pendapat mereka. Aku juga tidak mengungkapkan pendapat pribadiku,meskipun sebagian ayat memaksaku untuk berbicaraterkait pendapatku ataupun tentang seorangdari luar ahli sunnah. Namun aku hanya memberi informasi dan menyebutkan orang yang mengatakannya, sehingga pembaca menjadi jelas.

Sekalipun ia merujuk pada pendapat ulama, namun ia tidak pernah menyebutkan nama tokoh maupun karyanya secara spesifik. Ia hanya menggunakan kata: qala al-mufassirun, zahaba al-'ulama', qila, al-usuliyyun dan yuqalu. Sebagaimana contoh penafsirannya dalam Q.S. Al-Baqarah [2]: 243:

$$
\text { قال المفسرون إن الذين خرجوا من ديارهم ألوفا هم قوم من بنى إسرائيل أصاب قريتهم طاعون }
$$

Para ahli tafsir berkata, sesungguhnya ribuan orang yang keluar dari kampung halamannya adalah kaum Bani Israil yang desanya terkena wabah tha'un. 
Khazanah Theologia, Vol. 3 No. 1 (2021): 35-54

Karakteristik Tafsir al-Mushaf al-Mufassar karya Farid Wajdi

Wahyu Kusuma Aji

Dalam penafsirannya diatas nampak bahwasannya M. Farid Wajdi bersumber dari pendapat ahli tafsir. Hal ini berdasarkan kata qala al-mufassirun (para ahli tafsir berkata) dalam penafsirannya tersebut. Selain itu juga terlihat jika M. Farid Wajdi tidak menyebutkan ahli tafsir yang dirujuk secara spesifik.

Selain itu dalam contoh tafsir Q.S. Al-Baqarah [2]: 178:

$$
\text { قالمرأة الأصوليون: قوله الحر بالحر والعبد بالعبد والأنثى بالأنثى لا يدل على منع قتل الحر بالعبد والرجل }
$$

Para ahli usul berkata: ayat 'orang merdeka dengan orang merdeka, hamba sahaya dengan hamba sahaya, wanita dengan wanita,tidak menunjukkan atas dilarangnya orang merdeka dengan hamba sahaya, pria dengan wanita, mukmin dangan kafir.

Pada contoh tafsir tersebut tampak, bahwasannya M. Farid Wajdi merujuk kepada ulama' usul sebagai sumber penafsirannya. Penyebutan nama sumbernyapun tidak ditampilkan secara spesifik. Hal ini dapat dilihat jelas dengan redaksi qala al-usuliyyun (para ahli usul berkata) yang cenderung masih terlalu umum.

Demikian pula ketika M. Farid Wajdi merujuk pendapat ulama sunnah dalam contoh tafsir Q.S. AlA'raf [7]: 54:

$$
\begin{aligned}
& \text { (ثم استوى على العرش) أى ثم جلس على سرير الملك ـ وبما أن الله ليس بجسم ولا عرض فلا يجبوز أن } \\
& \text { يؤخذهذا الكلام على ظاهره بل يجب تأويله. وقد سلك علماء السنة هذا المسلك فقالوا: إن الإستواء } \\
& \text { على العرش صفة الله بلاكيف أى أن له تعالى أستواء على العرش على الوجه الذى عناه منزها عن } \\
& \text { الإستقرار والتمكن. وقالوا: العرش هو الجسم المحيط بسائر الأجسام. }
\end{aligned}
$$

(lalu dia bersemayam di atas 'arsy) yakni dia duduk disinggasana Tuhan. Sesungguhnya Allah tidak berjisim dan berbentuk,maka tidakdiperkenankan mengambil ayat ini secara lahiriah, melainkan mengharuskan adanya penakwilan terlebih dahulu. Para ulama' sunnah juga mengikuti hal ini. Mereka berkata, kalimat al-istiwa 'ala al-'arsy merupakan sifat Allah tanpa deskripsi. Yakni melepaskan Allah dari ruang dan waktu. Mereka berkata: arsy adalah Jisim yang meliputi segala jisim.

Di sini tampak bahwa ia merujuk pendapat ulama' sunnah, dengan ditandai dengan kata fa qalu. Di dalam kata fa qalu tersebut terdapat damir wawu jama'ah yang kembali ke kata ulama' al-sunnah yang terletak sebelumnya.

Berbagai contoh di atas menunjukkan, jika dalam kitab tafsir al-Mushafal-Mufassar, M. Farid Wajdi bersumber dengan pendapat ulama'. Meskipun pada praktiknya ia hanya menyebutkan kecendrungankecendrungan ulama' tersebut, seperti ulama' dengan kecendrungan ahli tafsir, usul dan lain sebagainya, tanpa disertai penyebutan nama secara spesifik. 


\section{Metode penafsiran}

Langkah yang ditempuh M. Farid Wajdi dalam menafsirkan Al-Qur'an tidak jauh beda dengan para mufassir sebelum-sebelumnya. Berdasarkan pengamatan langsung terhadap al-Mushaf al-Mufassar ada lima langkah metodis-praksis yang dipakai oleh M. Farid Wajdi.

\section{Interpretasi tekstual}

Metode interpretasi ini dilakukan dengan menafsirkan ayat-ayat Al-Qur'an, Hadis Nabi, Asar alSahabi, sya'ir, Isra'iliyyat (Mustaqim, 2008) dan pendapat para ulama' berdasarkan keahliannya. Berdasarkan pengamatan penulis, M. Farid Wajdi hanya menafsirkan Al-Qur'an dengan teks-teks tersebut kecuali sya'ir dan israiliyyat. Untuk lebih rincinya dapat dilihat pada contoh di bawah ini.

a. Menafsirkan ayat dengan ayat

metode ini dilakukan dengan menafsirkan bagian (kosa kata) dari ayat Al-Qur'an dengan ayat lainnya baik sama maupun berbeda ayat dan suratnya. Selain itu ada pula yang menafsirkan ayat dengan ayat lainnya baik sama maupun berbeda dari segi suratnya.

Jika ditilik dalam Kitab tafsir al-Mushaf al-Mufassar, maka metode ini telah dilakukan oleh M. Farid Wajdi pada contoh penafsirannya dalam konteks tafsir al-ma'ani Q. S. Yasin [36]: 7.

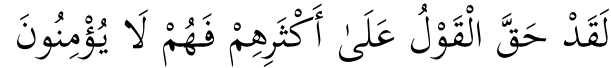

$$
\begin{aligned}
& \text { لقد وجب القول على أكثرهم (يعنى قوله لأملأن جهنم من الجنة والناس أجمعين ) فهم لا يؤمنون. }
\end{aligned}
$$

Sungguh, pasti berlaku perkataan (hukuman) terhadap kebanyakan mereka, karena mereka tidak beriman.

Sungguh, pasti berlaku perkataan (hukuman) terhadap kebanyakan mereka (yakni firman Allah "Pasti akan Aku penuhi neraka Jahanam dengan jin dan manusia bersama-sama") mereka yang tidak beriman.

Kalimat al-qaul 'ala aksarihim (ketentuan Allah terhadap kebanyakan mereka) pada Q. S. Yasin [36]: 7 diatas dinilai masih terlalu umum dan terkesan mubham. Karena belum jelas secara spesifik mengenai ketentuan Allah serta objek dari ketentuan tersebut. Sehinnga M. Farid Wajdi men-takhsis-nya dengan Q. S. Al-Sajdah [32]: 13:

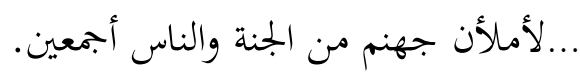

Pasti akan Aku penuhi neraka Jahanam dengan jin dan manusia bersama-sama.

Dengan menafsirkan menggunakan Q. S. Al-Sajdah [32]: 13 ini, maka tampaklah bahwa yang dimaksud pada lafal al-qaul 'ala aksarihim dalam Q. S. Yasin [36]: 7 adalah ketentuan Allah dalam Q. S. AlSajdah [32]: 13, yang berisi" akan memenuhi Neraka Jahannam dengan golongan manusia dan jin".

b. Menafsirkan ayat dengan hadis Nabi:

Sebagaimana ketika M. Farid Wajdi menafsirkan dalam konteks tafsir al-alfaz Q. S. Al-Taubah [9]: 72. 
Khazanah Theologia, Vol. 3 No. 1 (2021): 35-54

Karakteristik Tafsir al-Mushaf al-Mufassar karya Farid Wajdi

Wahyu Kusuma Aji

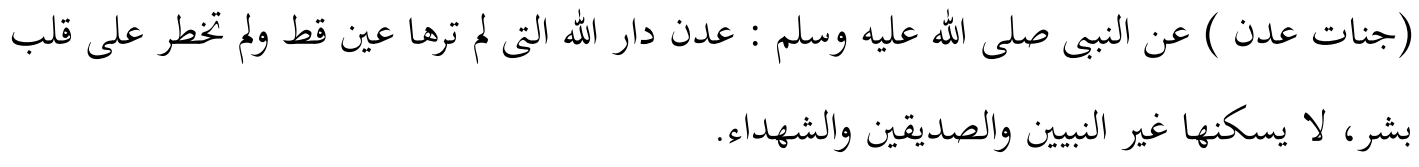

(Surga 'adn) berdasarkan hadis Nabi saw.: surga 'and adalah rumah Allah yang tidak dapat dilihat oleh mata manusia dan dirabaoleh pikiran manusia. Didalamnya tidak tinggal selain para Nabi, Sahabat dan Syuhada'.

Dalam menafsirkan Q. S. Al-Taubah [9]: 72 lafal جنات عند, M. Farid Wajdi menafsirkannya dengan hadis Nabi yang berarti "'adn adalah rumah Allah yang sama sekali tidak dapat dilihat melalui pandangan mata dan tidak terlintas dalam hati/pikiran manusia, di dalamnya hanya didiami/ditempati oleh para Nabi, sahabat-sahabat Nabi dan orang-orang yang mati syahid." Ketika mengutip hadis, M. Farid Wajdi tidak memperhatikan persoalan kualitas hadis tersebut. Hal ini berguna untuk menjaga penafsirannya agar tidak menjadi panjang lebar.

\section{c. Menafsirkan ayat dengan Asar al-Sahabi}

Salah satu contoh metode penafsiran ayat dengan Asar al-Sahabi ini sebagaimana penafsiran M. Farid Wajdi di bawah ini.

$$
\text { قال عاصم بن سليمان: سألت أنسا عن الصفا والمروة، قال كنا نرى أفما من أمور الجاهلية فلما جاء }
$$

'Asim bin Sulaiman berkata: aku bertanya kepada Anas terkait Safa dan Marwa, Anas menjawab, Safa Marwa awalnya merupakan tradisi Jahiliah. Ketika Islam datang keduanya tetap dipertahankan. Kemudian Allah berfirman: Sesungguhnya Safa dan Marwa merupakan tandatanda dari Allah.

Dalam menafsirkan Q.S. Al-Baqarah [2]: 158, M. Farid Wajdi menafsirkannya dengan riwayat 'Asim bin Sulaiman yang bertanya kepada Anas mengenai Safa dan Marwah. Kedua tokoh tersebut termasuk dalam golongan sahabat dikarenakan keduanya adalah orang yang mengenal dan membantu perjuangan Nabi Muhammad secara langsung dalam keadaan Islam.

d. Menafsirkan Ayat dengan pendapat ahli (ulama).

Metode penafsiran ini dilakukan dengan cara menafsirkan ayat Al-Qur'an dengan mengemukakan pendapat Ahli/ulama' dengan berbagai kecendrungan seperti ahli tafsir, Fikih, bahasa dan lain sebagainya. ditampilkannya pendapat-pendapat tersebut berguna untuk menguatkan penafsiran, selain itu juga berguna untuk perbandingan pendapat dan penafsiran M. Farid Wajdi dengan ulama' lainnya. Hal-hal tersebut dapat dilihat pada contoh penafsiran M. Farid Wajdi terhadap Q.S. Hud [11]: 40.

$$
\text { نقول: فار اتنور معناه الحرفن نبع اتنور. قال المفسرون: ومعناه أنه نبع الماء من التنور إعجازا. }
$$

Aku berkata: Fara attannur bermakna sumber air di tungku. Para ahli tafsir berkata: maknanya adalah bersumbernya air dari tungku merupakan bentuk mukjizat

Ketika menafsirkan kata وَفَارَ النتُّورُ dalam M. Farid Wajdi menambahkan pendapat ahli Tafsir yang menafsirkan kata tersebut dengan "memancarnya air dari tungku tersebut adalah mu'jizat". Dalam penyajiannya 
Khazanah Theologia, Vol. 3 No. 1 (2021): 35-54

Karakteristik Tafsir al-Mushaf al-Mufassar karya Farid Wajdi

Wahyu Kusuma Aji

diatas, M. Farid Wajdi hanya menggunakan istilah al-mufassirun (para ahli tafsir), tanpa menyebutkan secara spesifik mengenai nama tokoh yang dirujuk olehnya.

\section{Interpretasi Sosio-Historis}

Interpretasi ini dipahami dengan penafsiran menggunakan riwayat mengenai kehidupan sosipolitik dan kultural bangsa Arab pada saat turunnya,(Ghozali, 2010, hal. 87) dengan kata lain ayat ditafsirkan dengan asbab al-nuzulnya. Interpretasi ini ditempuh dengan mengemukakan peristiwa suatu ayat yang akan ditafsirkan apabila ayat tersebut turun berdasarkan suatu peristiwa.

Adapun M. Farid Wajdi dalam menafsirkan Al-Qur'an, selain ia mengemukakan peristiwa-peristiwa yang bersifat mikro (berdasarkan riwayat Hadis Nabi dan Asar al-sahabi), ia terkadang juga mengemukakan peristiwa-peristiwa yang makro (sebab-sebab umum atau situasi dan kondisi dalam lingkup lebih luas seperti seting sosial, geografis, politik, budaya dan lain-lain yang menyertai turunnya ayat). Contoh penafsiran M. Farid Wajdi untuk asbab al-nuzul mikro tertera dalam Q.S. Al-Baqarah [2]:106 yang isinya sebagai berikut:

$$
\text { هزلت هذه الاية لما قال المشركون واليهود : الا ترون أن محمدا يأمر أصحابه بأمر تخم ينهاهم عنه و يأمر }
$$

ayat tersebut turun ketika orang-orang musyriq dan Yahudi berkata "apakah kalian tidak melihat, bahwa Muhammad memberi perintah akan suatu perkara terhadap para sahabatnya, kemudian ia sendiri melarang perkara tersebut dan menggantinya dengan perintah yang bertentangan".

Dalam menafsirkan ayat tersebut M. Farid Wajdi menjelaskan bahwa ayat tersebut turun ketika orangorang musyriq dan Yahudi berkata "apakah kalian tidak melihat, bahwa Muhammad memberi perintah akan suatu perkara terhadap para sahabatnya, kemudian ia sendiri melarang perkara tersebut dan menggantinya dengan perintah yang bertentangan".

Sedangkan contoh untuk asbab al-nuzul makro tertera dalam penafsira M. Farid Wajdi terhadap Q.S. al-Maidah [5]: 3 .

$$
\begin{aligned}
& \text { (وان تستقسموا بالأزلام) والإستقسام طلب معرفة ما قسم للشخص. والأزلام جمع زلم وهو سهم لا } \\
& \text { ريش عليه. كان من عادةالعرب إذا قصدوا أن يفعلوا شيأ أن يأتوا بثلاثة سهام مكتوب على أحدها } \\
& \text { أمرنى ربى وعلى الثانى فانى ربى ويتركون الثالث غفلا بلا كتابة، فإذا خرج أحد الأولين فعل أو ترك، } \\
& \text { وإذا خرج الثالث أجال السهام حتى يخرج له شئ. }
\end{aligned}
$$

(mengundi nasib dengan anak panah) mengundi nasib adalah mencari tahu terkait seseorang yang terpilih undian. Sedangkan kata al-azlam adalah jamak dari kata zilmun yakni anak panah tanpa bulu. Ini merupakan budaya Arab ketika hendak melakukan sesuatu maka mengambil tiga anak panah. Padaanak panah pertama tertulis "Tuhan memerintahku", kedua "Tuhan melarangku" maka kalian tinggalkan. Ketiga, kosong tanpatulisan. Bagi seseorang yang mendapat anak panah pertama dan kedua, otomatis melakukan dan meninggalkan. Sedangkan bagi yang mendapat panah ketiga harus mengambil ulang undian 
Khazanah Theologia, Vol. 3 No. 1 (2021): 35-54

Karakteristik Tafsir al-Mushaf al-Mufassar karya Farid Wajdi

Wahyu Kusuma Aji

Dalam penafsirannya terhadap lafal al-azlam pada Q.S. al-Maidah [5]: 3 di sini, M. Farid Wajdi mengeksplor lebih jauh makna dari lafal tersebut. Ia melakukannya dengan menghadirkan praktik alazlam dalam kebudayaan bangsa Arab. sehingga dapat diketahui bahwasannya al-azlam berdasarkan kebudayaan Arab yang merupakan tempat dimana Al-Qur'an turun adalah, tiga buah anak panah tanpa bulu yang digunakan untuk mengundi nasib. Pada anak panah pertama terdapat tulisan "Tuhan memerintahku", lalu anak panah kedua bertuliskan "Tuhan melarangku" dan untuk panah ketiga kosong tanpa ada tulisan. Bagi seseorang yang mendapat anak panah pertama dan kedua, otomatis melakukan dan meninggalkan. Sedangkan bagi yang mendapat panah ketiga harus mengambil ulang undian.

Dengan ditampilkannya gambaran mengenai contoh kebudayaan tersebut, maka makna dari kata itupun tidak terkesan harfiah dan dapat difahami secara gamblang berdasarkan konteks kultural tempat dimana Al-Qur'an turun.

\section{Interpretasi linguistik}

Metode ini dilakukan dengan cara menafsirkan ayat dengan menggunakan kaidah-kaidah tata bahasa Arab seperti semantik morfologis yaitu makna yang di peroleh berdasarkan bentuk tasrif lafaz, semantik etimologis yang membahas arti dari struktur dasar bahasa Arab dan semantik leksikal yaitu makna yang diperoleh dari kamus.

Hal ini dapat dilihat dalam penafsiran M. Farid Wajdi pada Q. S. Al-Kafirun [109]: 2

$$
\begin{aligned}
& \text { (لا أعبد ما تعبدون ) أى لا أعبد آلنكم فيما يستقبل، فإن (( لا)) لا تدخل إلا على مضارع بمعنى } \\
& \text { الإستقبال كما أن (ما)) لا تدخل إلا على مضارع بمعنى الحال. }
\end{aligned}
$$

(Aku tidak menyembah yang kamu sembah) yakni aku tidak menyembah tuhan kalian sampai waktu yang akan datang. Adapun lafaz ' $l a$ ' tidak masuk selain pada fi'il mudhari' dengan makna istiqbal sebagaimana ' $m a$ 'tidak masuk kecuali pada fi' il mudhari' bermakna hal.

Dalam menafsirkan Q. S. Al-Baqarah [2]: 2 tersebut, M. Farid Wajdi menjelaskan bahwa huruf $\vee$ hanya masuk pada fi'il mudari' yang memiliki makna istiqbal (waktu yang akan datang), berbeda dengan huruf $\downarrow$ yang hanya masuk pada fi'il mudari' yang memiliki makna hal (waktu sekarang).

\section{Interpretasi sistemik}

Metode interpretasi sistemik ini difahami sebagai munasabah (keterkaitan) antara ayat satu dengan ayat yang lainnya atau munasabah surah dengan surah lainnya (Ghozali, 2010, hal. 86).

Metode ini dilakukan, ketika M. Farid Wajdi menafsirkan ayat Al-Qur'an dengan menyisipkan kata ta'lil guna menjelaskan sebab akibat antara satu ayat dengan ayat sebelumnya. Hal ini dapat dilihat pada penafsiran M. Farid Wajdi dalam Q. S. Saba'[34]: 4-5.

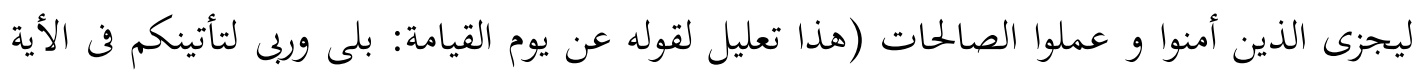

Sebagai balasan bagi orang mukmin dan orang-orang yang beramal soleh (ini merupakan ta'lil terkait firman Allah tentang hari Qiyamat: "iya, demi Tuhanku akan datang kepada kalian... pada ayat sebelumnya). 
Khazanah Theologia, Vol. 3 No. 1 (2021): 35-54

Karakteristik Tafsir al-Mushaf al-Mufassar karya Farid Wajdi

Wahyu Kusuma Aji

Ketika M. Farid Wajdi menafsirkan Q. S. Saba': 4-5 (li yajziy al-lazina amanu wa'amilu al-salihat), ia menjelaskan bahwa ayat ini merupakan alasan dari adanya ayat sebelumnya yakni Q. S. Saba'[34]: 3 (bala warabbi la ta'tiyannakum). Sehingga dapat diartikan bahwa alasan Allah mendatangkan hari Qiyamat guna memberikan balasan bagi amal-amal yang dilakukan oleh orang-orang mukmin dan kafir. Maka dari itu M. Farid Wajdi menganggap adanya keterkaitan (munasabah) dari kedua ayat tersebut.

Hal serupa dilakukan M. Farid Wajdi ketika menafsirkan Q. S. Al-Ahzab [33]: 73.

$$
\begin{aligned}
& \text { ليعذب الله المنافقين والمنافقات والمشركين والمشركات، ويتوب الله على المؤمنين والمؤمنات، وكان الله غفورا } \\
& \text { رحيما. هذا تعليل لحمل الأمانة التى ذكرها الله في الآيات السابقة. }
\end{aligned}
$$

sehingga Allah akan mengazab orang-orang munafik laki-laki dan perempuan, orang-orang musyrik, laki-laki dan perempuan; dan Allah akan menerima tobat orang-orang mukmin laki-laki dan perempuan. Dan Allah Maha Pengampun, Maha Penyayang. Ayat ini merupakan ta'lil kepada pembawa amanah yang Allah sebutkan pada ayat sebelumnya.

Dalam penafsirannya tersebut, M. Farid Wajdi menjelaskan bahwa Q. S. Al-Ahzab [33]: 73 (li yu'aziba Allah al-munafiqina wa al-munafiqat wa al-musyrikina wa al-musyrikati), itu adalah ta'lil (alasan) atas ayat sebelumnya yakni Q. S. Al-Ahzab [32]: 72 (inna 'aradna al-amanah 'ala al-samawati wa al-ardi). Keterkaitan ini merupakan munasabah antar ayat satu dengan ayat sebelumnya ataupun setelahnya.

\section{Corak Penafsiran}

Dalam menafsirkan ayat-ayat Al-Qur'an, M. Farid Wajdi sebenarnya tidak memiliki kecendrungan khusus menggunakan satu corak yang spesifik secara mutlak, semisal bercorak lugawi saja, bercorak fiqhi saja atau yang lainnya. Namun, secara garis besar tafsir ini cenderung mendominasi corak lugawi. hal ini dapat dilihat dari penafsirannya dengan mengungkap istilah dan kata-kata yang kurang jelas dengan menghadirkan sinonim-sinonimnya dan juga sering ditambahkan kaidah-kaidah tata bahasa seperti tasrif dan jenis kata. Hal ini tidak bisa terlepas dari latar belakang dirinya sebagai sastrawan dan ahli bahasa yang ditandai dengan karya besarnya Da'irah Ma'arif Al-Qarn Al-'Isyrin (ensiklopedi abad duapuluh).

Sebagaimana penafsirannya terhadap kosa kata dalam Q.S. Al-An'am [6]:145:

$$
\begin{aligned}
& \text { (ميتة) الميتة ما تركته الروح من الحيوان من غير تذكية. (مسفوحا) أى مصبوبا. يقال سفح دمه يسفحه } \\
& \text { سفحا أى سفكه. (رجس) أى قذر . يقال رجل رجس و رجال أرجاس. (أو فسقا) معطوف على لحم } \\
& \text { خنزير، والمراد به ذبيحة لم يذكر إسم الله عليها. (أهل لغير الله به) أى ذكر غير الله عند ذبحه. يقال } \\
& \text { أهل باسم الله أى قال بسم الله. (غير باغ) أى غير ظالم. يقال عليه يبغوا أى أعتدى. أما بغى يبغى } \\
& \text { بغا و ببغاء و بغية وبغية فمعناه طلب وأراد. (ولا عاد) أى ولا معتد. يقال عدا يعدو عدوا أى اعتدى. }
\end{aligned}
$$

(bangkai) hilangnya ruh dari bintang tanpa proses penyembelihan. (tertumpah) yakni mengalir. Dikatakan "darahnya telah/sedang/akan benara-benar mengalir. (keji) yakni kotor. Orang/orang-orang yang keji. (lafal fisqan) ma'tuf terhadap lafaz lahma khinzir. Yang dimakasud di sini ialah sembelihan tanpa menyebut nama Allah. (menyembelih kepada selain Allah) yakni menyebut selain Allah pada proses penyembelihannya. dikatakan menampakkan bismillah yakni mengucapkan bismillah. (tidak 
Khazanah Theologia, Vol. 3 No. 1 (2021): 35-54

Karakteristik Tafsir al-Mushaf al-Mufassar karya Farid Wajdi

Wahyu Kusuma Aji

menginginkannya) yakni tidak zalim. Dikatakan "orang-orang yang menginginkan yakni orang yang melewati batas". Adapun bentuk tasrif nya adalah baga-yabga-bagan/biga'an/bugyatan/bigyatan maknanya mengharap dan menginginkan. (dan tidak melampaui batas) yakni sombong. Tasrifannya 'adaya'du- 'adwan yakni "menyalahi".

Pada contoh ini tampak jika M. Farid Wajdi mengungkap makna kata dari aspek kebahasaan. Seperti penafsirannya terhadap kata masfuhan. Ia menjelaskan tasrif -nya yang berasal dari kata safiha, yasfahu, safhan. Demikian pula dengan kata bagin dengan tasrif nya baga, yabga, bagan, wa biga>'un, wa bigyatan, wa bugyatan dan kata 'adin yang berasal dari 'ada, ya'du, 'adwan. Dengan dijelaskannya tasrif dari kata tersebut, maka dapat diketahui musytaq (akar kata) dan proses perubahan kata.

Selain itu ia juga menjelaskan bahwasannya kata fisqan merupakan ma'tuf (mengikuti) kata lahma khinzirin. Oleh sebab itu kata fisqan dibaca fathah sebagaimana pada kata lahma. Sedangkan untuk rijsun, M. Farid Wajdi bermaksud untuk menjelaskan bahwa bentuk kata tersebut adalah mufrad tanpa diberi istilah secara spesifik. Ia hanya memberikan contoh kalimat rajulun rijsun (bentuk mufrad) dan rijalun arjasun (bentukjama).

Demikian pula pada contoh penafsiran Q.S. Al-Kafirun [109]: 2

$$
\text { (الإستقبال كما أن(ما)) لا تدخد ما تعبدون ) أى لا أعبد آلهتكم فيما يستقبل، فإن (( لا)) لا تدخل إلا على مضارع بمعنى }
$$

(Aku tidak menyembah yang kamu sembah) yakni aku tidak menyembah tuhan kalian sampai waktu yang akan datang. Adapun lafaz ' $l a$ ' tidak masuk selain pada fi'il mudhari' dengan makna istiqbal sebagaimana ' $m a$ 'tidak masuk kecuali pada fi' il mudhari' bermakna hal.

Dalam menafsirkan Q. S. Al-Kafirun [109]: 2 ini, M. Farid Wajdi menjelaskan bahwa huruf ע hanya masuk pada fi'il mudari' yang memiliki makna istiqbal (waktu yang akan datang), berbeda dengan huruf yang hanya masuk pada fi'il mudari' yang memiliki makna hal (waktu sekarang).

\section{Karakteristik al-Mushaf al-Mufassar}

\section{Postur Tafsir}

Kesan pertama yang dominan dalam tafsir al-Mushaf al-Mufassar adalah postur penulisan tafsirnya yang simpel nan lugas. Setiap bahasan tafsirnya selalu disajikan dalam satu halaman tuntas, tidak lebih. Berbeda dengan karya tafsir sebelumnya yang umumnya menghabiskan banyak halaman untuk satu uraian tafsirnya seperti Jami' al-Bayan 'an ta'wil ay Tafsir al-Qur'an karya al-Tabari, al-Kasysyaf karya alZamakhsyari, dan al-Manar karya M. 'Abduh dan Rasyid Rida, misalnya . Postur semacam ini memberi kesan bahwa tafsir bagi M. Farid Wajdi bukan sekadar uraian (penjelasan) panjang nan bertele-tele atas suatu ayat yang hendak ditafsirkan namun justru membuat pembaca kesulitan dalam memahami pesan intinya. Melainkan lebih kepada penjelasan 'yang cukup' dan pesan intinya mudah dimengerti oleh pembaca.

Meskipun prinsip yang dianut dalam postur penulisan al-Mushaf al-Mufassar adalah simpel dan lugas, namun konsepnya berbeda dengan kitab-kitab tafsir yang mukhtasar. Perbedaan tersebut terletak pada orentasinya. Menurut M. Farid Wajdi, kitab-kitab mukhtasar pada umumnya cenderung fokus dan terbatas pada persoalan-persoalan di bidang tertentu saja. Selain itu, orientasi uraiannya pun lebih 
Khazanah Theologia, Vol. 3 No. 1 (2021): 35-54

Karakteristik Tafsir al-Mushaf al-Mufassar karya Farid Wajdi

Wahyu Kusuma Aji

cenderung pada pemenuhan wacana materi disiplin keilmuan tertentu ketimbang memberikan penjelasan mengenai pesan ayat yang dapat dipahami secara mudah oleh pembaca. Sedangkan al-Mushaf al-Mufassar selain berorientasi pada pemenuhan kaidah tafsir juga memperhatikan kemudahan pemahaman pembaca (Wajdi, t.th.).

Diferensiasi al-Mushaf al-Mufassar terhadap karya tafsir lainnya pun tercermin dalam postur penyajian ayat-ayat yang hendak ditafsirkan. Dalam menuliskan tafsirnya M. Farid Wajdi menampilkan ayat-ayat yang hendak ditafsirkan sesuai dengan tampilan mushaf. Ia menempatkan ayat-ayat tersebut dalam sebuah kolom, kemudian ia memberikan tafsir al-alfaz di bagian sampingnya (hawamisy) dan tafsir al-ma'ani di bagian bawahnya. Berbeda dengan tafsir lainnya seperti Ma'alim al-Tanzil karya Al-Bagawi, Jami' al-Ahkam Al-Qur'an karya Al-Qurtubi, Jami' al-Bayan 'an ta'wil ay Tafsir al-Qur'an karya al-Tabari, alKasysyaf karya al-Zamakhsyari, al-Manar karya M. 'Abduh dan Rasyid Rida, dan Tafsir Al-Qur'an Al-'Azim karya Ibnu Kasir, misalnya. Semua karya tafsir tersebut biasanya menampilkan satu atau sekelompok ayat kemudian ditafsirkan. Bahkan postur penyajian antara ayat dan uraian tafsirnya dicampur dalam satu pembahasan. Selain itu, beberapa kitab tafsir tersebut tidak membuat bab tersendiri yang berisi khusus penjelasan tafsir al-alfaz sebagaimana yang dilakukan M. Farid Wajdi.

Postur penulisan tafsir M. Farid Wajdi tersebut memiliki kesan bahwa ia ingin memberikan kemudahan dan kenyamanan bagi pembaca ketika membaca karya tafsirnya. Sebagaimana pandangannya bahwa karya-karya tafsir terdahulu memiliki postur yang amat menjemukan. Hal itu dikarenakan pembahasannya yang bertele-tele, penulisan ayat dan uraian tafsirnya dicampur, dan penggunaan bahasa yang ribet, sehingga pembaca justru kesulitan dalam memahami pesan utamanya.

Oleh karena itu, bisa dikatakan bahwa postur penyajian tersebut memuat dualisme fungsi kitab, yakni sebagai mushaf sekaligus tafsir. Pembaca bisa membaca ayat-ayat Al-Qur'an melalui karya tersebut, juga bisa memahami arti tafsrinya. Fungsi ini tidak akan bisa ditemukan dalam tafsir al-Jalalain karya Jalaluddin al-Mahalli dan al-Suyuti, misalnya. Sebab, hampir setiap kata dalam ayat selalu dipotong dengan penafsiran, sehingga pembaca tidak dapat membaca teks Al-Qur'annya sebagai mushaf.

Aspek lain yang menjadi distingsi karya M. Farid Wajdi adalah meyajikan tafsir al-alfaz dalam sub pembahasan tersendiri sebagai hawamisy (catatan pinggir). Bahkan menurut M. Farid Wajdi Postur demikian belum pernah dilakukan oleh mufasir-mufasir sebelumnya. Sekalipun ada, namun (1) posturnya tidak disajikan dalam bab tersendiri, melainkan dicampur dengan uraian tafsirnya; dan (2) merupakan kitab khusus yang membahas tentang arti kosa kata yang ada dalam Al-Qur'an seperti al-Mufradat fi garib Al-Qur'an karya al-Ragib al-Asfahani.

Lantas bagaimana dengan Tafsir Al-Qur'an al-Karim karya al-Maragi dan Safwat al-Tafasir karya 'Ali al-Sabuni yang juga menyertakan tafsir al-mufradat? jika dirunut berdasarkan sejarah, tafsir al-Mushaf al-Mufassar karya M. Farid Wajdi ini ditulis lebih dulu daripada kedua tafsir tersebut. Indikasinya adalah bahwa tafsir al-Mushaf al-Mufassar selesai ditulis pada tahun 1948 dan diterbitkan pada tahun tersebut pula. Sementara kitab Tafsir Al-Qur'an al-Karim karya al-Maragi selesai ditulis pada tahun 1949 dan diterbitkan pada tahun 1950. Sedangkan Safwat al-Tafasir karya 'Ali al-Sabuni baru selesai ditulis pada tahun 1961.

Selain aspek sejarah penulisannya, karya tafsir M. Farid Wajdi selalu mengulang kata yang sudah dijelaskan di awal. Misalnya kata ruh al-qudus pada Q.S. Al-Baqarah [2]: 87, al-Baqarah [2]: 253 dan alMaidah [5]: 110. Pada Q.S. Al-Baqarah 87, M. Farid Wajdi menjelaskan bahwa ruh al-qudus adalah 'ruh yang disucikan' maksudnya adalah malaikat Jibril, Nabi 'Isa, Injil dan Nama Allah yang diagungkan. Sedangkan dalam al-Baqarah: 253 dan al-Maidah: 110 M. Farid Wajdi lebih memberikan penjelasan spesifik bahwa kata ruh al-qudus adalah malaikat Jibril. 
Khazanah Theologia, Vol. 3 No. 1 (2021): 35-54

Karakteristik Tafsir al-Mushaf al-Mufassar karya Farid Wajdi

Wahyu Kusuma Aji

Pengulangan yang ia lakukan tersebut bertujuan untuk lebih memperkuat dalam memahami ragam makna pada satu kata yang ada di dalam Al-Qur'an. Selain itu, diharapkan agar mempermudah pembaca dalam menghafal kosa kata Al-Qur'an. Sebagaimana ia katakan:

$$
\text { وانحن أحوج ما نكون الى التقوى فيها لنحفظ وجودها من غبث العجمة بها. فشرحنا المفردات شرحا }
$$

Dan kita itu masih membutuhkan untuk penguatan bahasa agar kita dapat menghafal adanya mufradat tersebut dengan tanpa adanya campuran bahasa asing, maka dari itu saya butuh untuk mensyarahi kata perkata dengan syarah yg cukup luas, dan kami tunjukkan asalnya kata ini, dan kami juga memaparkan kata pecahan, dan saya selalu menyanggupi untuk mensyarahi lafaz sekira saya menemukan syarahnya, itupun saya memadukan dengan kata kata yang ada pada halamanhalaman yang lain, dan ini juga belum pernah di lakukan oleh mufasir-mufasir yang lainnya, di karenakan mufasir-mufasir yang lain ketika sudah menemukan satu lafaz dalam satu surat maka ketika dia menemukan lafaz yang sama dalam surat yang lain dia sudah tidak membahasnya lagi, ini yang berbeda dengan yang saya lakukan kalau saya meskipun saya menemukan lafaz itu saya terus mensyarahinya, meskipun berulang kali di surat yang berbeda.

Pernyataannya dalam mukadimah di atas, tentunya akan semakin memperkuat alasan mengenai penggunaan karakter dalam penulisan tafsir al-alfaz dalam kitab tafsirnya.

\section{Struktur dan Gaya Bahasa Tafsir}

Dalam menafsirkan Al-Qur'an, M. Farid Wajdi menggunakan struktur dan gaya bahasa yang lugas. Bahkan seringkali menggunakan bahasa Al-Qur'an itu sendiri Penggunaan struktur dan gaya bahasa secamam ini bukanlah tanpa alasan, sebagaimana ia katakan:

$$
\begin{aligned}
& \text { وقد راعيت في تفسيري هذا أن أعني باللغة عناية لم يعن بها مفسر من السابقين,فافم فيما يظهر لغزارة } \\
& \text { ما دتمم اللغاوية لم يلموا من لغة القرأن الا بالعريب اللذي يعلوعن متناول كثير من الخاصة. ولكني رأيت } \\
& \text { أن الكتاب الكريم قد جمع أوجه كلمات اللغة العرابية، وعقائل مفردتما . }
\end{aligned}
$$

Dalam tafsirku ini saya menyajikan bahasa yang belum pernah di lakukan oleh mufasir-mufasir sebelumku, karena bahan mereka dalam urusan bahasa itu sangat banyak maka mereka menulis tafsir Al-Quran dengan bahasa yang sangat tinggi, sampai-sampai sedikit orang yang memahaminya, dan saya memandang bahwasanya Al-Qur'an al-karim telah mencakup beberapa aspek kalimat bahasa Arab, dan mufradat-mufradat yang dapat di cerna oleh akal

Berdasarkan pernyataan tersebut setidaknya ada dua alasan mengapa ia menggunakan struktur dan gaya bahasa yang lugas. Pertama, banyak karya tafsir terdahulu menggunakan bahasa penafsiran yang tergolong berat nan tinggi (muluk) dan bertele-tele. Misalnya al-Kasyaf karya al-Zamakhsyari, 
Khazanah Theologia, Vol. 3 No. 1 (2021): 35-54

Karakteristik Tafsir al-Mushaf al-Mufassar karya Farid Wajdi

Wahyu Kusuma Aji

Mafatih al-Gaib karya al-Razi, tafsir al-Qur'an al-'Azim karya Ibnu Kasir, Lubab al-Ta'wil fi Ma'an al-Qur'an karya al-Khazin, Ma'alim Tanzil karya al-Bagawi dan lain sebagainnya. Semua tafsir tersebut uraiannya menggunakan bahasa yang tergolong berat dan bertele-tele. Sehingga selain tampak "membingungkan" pun seringkali uraiannya keluar dari inti pembahasan. Bahkan hanya kalangan tertentu yang mampu memahaminya. Sedangkan kalangan awam akan merasa kesulitan untuk memahaminya.

Kedua, bagi M. Farid Wajdi, Al-Qur'an sudah mengandung kosa kata Arab. Bagaimanapun Al-Qur'an diturunkan dengan bahasa Arab: bi lisanin 'arabiyyin (Q.S. al-Syu'ara' [26]: 195) maupun qur'anan 'arabiyyan (Q.S. Yusuf [12]: 2, Q.S. Taha [20]: 13, Q.S. al-Zumar [39]: 28, Q.S. Fusilat [41]: 3, Q.S. al-Syura [42]: 7, dan Q.S. al-Zukhruf [43]: 3). Lantaran diturunkan dan menggunakan bahasa Arab, sehingga Alqur'an tidak keluar dari unit kebahasaan yang ada di masyarakat Arab, mulai dari tingkat diksi hingga narasi. Berangkat dari asumsi inilah M. Farid Wajdi dalam tasirnya menggunakan bahasa ayat Al-Qur'an sebagai bahasa tafsirnya.

Selain itu, penggunaan bahasa yang lugas sebagai bahasa tafsirnya secara tidak langsung menjadi kritik atas tradisi tafsir terdahulu. Menurutnya, karya-karya tafsir lawas-yang umumnya berukuran tebal berjilid-jilid—selalu menggunakan bahasa tafsir yang panjang dan berbelit-belit. Sehingga memerlukan waktu yang cukup lama untuk membacanya, apalagi memahaminya (Wajdi, t.th.).

Di sisi lain, penggunaan bahasa tafsir yang lugas merupakan bagian dari strategi M. Farid Wajdi sebagai penulis. Ada beberapa argumentasi yang mendasarinya. Pertama, minat masyarakat Mesir kala itu terhadap tafsir bisa dikatakan cukup tinggi. Hal itu bisa dibuktikan dengan maraknya kajian tafsir, baik di lingkungan akademik seperti universitas maupun halakah pengajian di masjid-masjid. Hanya saja, minat tinggi masyarakat tersebut dihadapkan dengan kenyataan bahwa karya-karya tafsir terdahulu posturnya tebal dan berjilid-jilid, menggunakan bahasa yang bertele-tele dan rumit. Sehingga mereka menemukan beragam kesulitan dalam membaca, apalagi memahaminya. Atas dasar itulah, M. Farid Wajdi menulis tafsir dengan menggunakan bahasa sesuai kebutuhan masyarakat, bahasa tafsir yang sederhana namun berisi. Kedua, sebagai seorang penulis, M. Farid Wajdi berpandangan bahwa bahasa adalah modal sekaligus strategi dalam penyampaian pesan. Penggunaan bahasa yang bertele-tele dan rumit terkadang mengaburkan pesan yang hendak disampaikan. Dalam konteks penafsiran, struktur dan gaya bahasa bisa menjadi indikasi kepemahaman persoalan seorang mufasir dalam menguraikan suatu kandungan ayat (Gusmian, 2003). Ketiga, melalui penggunaan bahasa yang lugas, M. Farid Wajdi sebenarnya sedang berkompetisi dalam merebut 'pasar konsumsi tafsir', jika memang usahanya menulis tafsir al-Mushaf alMufassar diposisikan dalam konteks persaingan yang lazim di dunia kepenulisan. Ia menawarkan tafsir yang sangat simpel nan lugas, baik postur maupun bahasanya. Sebab, jauh sebelum M. Farid Wajdi membuat karya tafsir, konon M. Abduh pernah memperkenalkan kitab tafsir Jalalain kepada masyarakat melalui sebuah halakah pengajian dan terbukti mendapat perhatian cukup tinggi (Al-Bayumi, 2003). Perlu diketahui bahwa tafsir Jalalain adalah sebuah kitab tafsir yang praktis, berbeda dengan kebanyakan kitab tafsir semasanya yang umumnya tebal dan berjilid-jilid. Hanya saja, M. Farid Wajdi melihat bahwa tafsir tersebut sekalipun praktis namun masih terkendala dalam hal posturnya. Karena itu, melalui al-MushafalMufassar ia berharap kekurangan yang ada pada postur tafsir Jalalain bisa dijadikan modal untuk sebuah karya tafsir praktis yang ideal.

Kesan lain yang dominan dalam bahasa tafsir M. Farid Wajdi adalah penggunaan struktur bahasa Al-Qur'an itu sendiri. Misalnya ketika ia menafsirkan Q. S. Nuh [71]: 28.

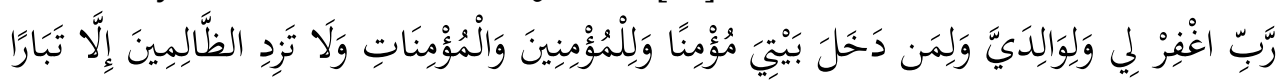


Khazanah Theologia, Vol. 3 No. 1 (2021): 35-54

Karakteristik Tafsir al-Mushaf al-Mufassar karya Farid Wajdi

Wahyu Kusuma Aji

$$
\text { رب اغفر لي ولوالدي ولمن دخَل بيتي مؤمناولمؤمنينَ والمؤمنات ولا تَزد الظالمين إلَّاَهلاكا }
$$

Ya Tuhanku, ampunilah aku, ibu bapakku, dan siapa pun yang memasuki rumahku dengan beriman dan semua orang yang beriman laki-laki dan perempuan. Dan janganlah Engkau tambahkan bagi orang-orang yang zalim itu selain kebinasaan."

Ya Tuhanku, ampunilah aku, ibu bapakku, dan siapa pun yang memasuki rumahku dengan beriman dan semua orang yang beriman laki-laki dan perempuan. Dan janganlah Engkau tambahkan bagi orang-orang yang zalim itu selain kehancuran."

Bila diperhatikan penafsirannya tersebut, maka tampak jika M. Farid Wajdi menggunakan bahasa Al-Qur'an sendiri ketika menafsirkan ayat tersebut. bahkan ia hanya mengganti kata tabaran dengan sinonimnya, halakan. Begitu juga ketika ia menafsirkan Q.S. Al-'Alaq [96]: 1-5:

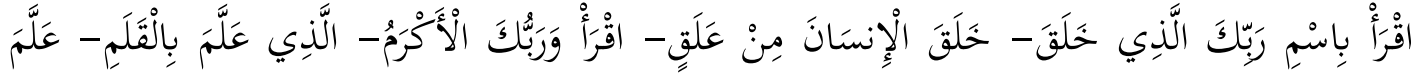

$$
\begin{aligned}
& \text { الْإِنسَانَ مَا لََْْ يَعْلَمْ } \\
& \text { اقْرأ بِاسم ربك الذي خَلق الانسان من دم متجمد. اقرأ وربك الأكرم، الذي علم خط بالقلم، علم }
\end{aligned}
$$

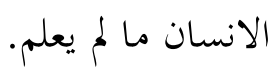

Bacalah dengan (menyebut) nama Tuhanmu yang menciptakan, Dia telah menciptakan manusia dari segumpal darah, Bacalah, dan Tuhanmulah Yang Mahamulia. Yang mengajar (manusia) dengan pena. Dia mengajarkan manusia apa yang tidak diketahuinya.

Bacalah dengan menyebut nama Tuhanmu yang menciptakan, Dia telah menciptakan manusia dari segumpal darah, Bacalah, dan Tuhanmulah Yang Mahamulia. Yang mengajar manusia menulis dengan pena. Dia mengajarkan manusia apa yang tidak diketahuinya.

Kelima ayat tersebut nampak sekali kalau M. Farid Wajdi menggunakan bahasa Al-Qur'an, terlebih pada ayat pertama, ketiga dan kelima, yang sama persis dengan ayat yang ditafsirkan. sedangkan pada ayat kedua M. Farid Wajdi memotong kata khalaqa, kemudian menggunakan kata khalaqa yang terdapat pada ayat pertama, selain itu ia juga menjelaskan kata 'alaq dengan damin mutajammidin. Sementara pada ayat keempat M. Farid Wajdi hanya menambahkan kata khattun setelah kata 'allama.

\section{SIMPULAN}

Berdasarkan uraian yang telah dikemukakan, maka dapat disimpulkan bahwa, Pertama, karakter khas al-Mushaf al-Mufassar tercermin pada dua aspek: (1) postur tafsir yang simpel dan lugas dengan corak tekstual-lugawi yang dikemas secara ijmali. Postur tafsirnya yang simpel dan lugas tersebut dapat ditengarai pada setiap bahasan tafsirnya selalu disajikan dalam satu halaman tuntas, tidak lebih. Selain itu, layout penulisan dan penyajian tafsirnya pun lebih berorientasi pada kemudahan dan kenyamanan bagi pembaca, yakni adanya penempatan secara proporsional antara teks ayat yang hendak ditafsirkan, tafsir al-alfaz dan tafsir al-ma'ani: teks ayat disajikan secara mushafi, sementara tafsir al-alfaz ditempatkan persis di bagian samping sebagai hawamisy, sedangkan tafsir al-ma'ani ditempatkan di bagian bawah sebagai tafsiran makna ayat secara global; (2) struktur dan gaya bahasa tafsir yang sederhana. Bahasa 
Khazanah Theologia, Vol. 3 No. 1 (2021): 35-54

Karakteristik Tafsir al-Mushaf al-Mufassar karya Farid Wajdi

Wahyu Kusuma Aji

tafsir yang lugas, tidak bertele-tele. Bahkan kerap menggunakan struktur kebahasaan Al-Qur'an itu sendiri.

Kedua, penggunaan karakter postur dan bahasa tafsir yang simpel dan lugas tersebut, di satu sisi bisa dikatakan sebagai kritik atas tradisi tafsir sebelum-sebelumnya, dan di sisi lain sebagai bagian dari strategi M. Farid Wajdi dalam konteks persaingan "pasar konsumsi tafsir" di Mesir. Dikatakan sebagai kritik atas tradisi tafsir sebelum-sebelumnya lantaran kenyataan bahwa karya-karya tafsir terdahuluyang umumnya tebal dan berjilid-jilid — cenderung bertele-tele uraiannya sehingga menjenuhkan dan membuat pembaca kesulitan untuk membacanya, apalagi memahaminya. Sedangkan dikatakan sebagai strategi dalam persaingan "pasar konsumsi tafsir" karena kenyataan bahwa minat masyarakat Mesir terhadap tafsir kala itu cukup tinggi. Namun minat tinggi mereka dihadapkan dengan kondisi kitab-kitab tafsir terdahulu yang tebal, berjilid-jilid, uraiannya bertele-tele. Sehingga mereka membutuhkan karya tafsir yang simpel, praktis dan lugas pembahasannya.

\section{REFERENSI}

Abdullah, A. (2003). Arah Baru Metode Penelitian Tafsir di Indonesia. In Khazanah Tafsir di Indonesia. Jakarta: Teraju.

Al-Bayumi, M. R. (2003). Muhammad Farid Wajdi: al-Katib al-Islami al-Mufakkir al-Mausu'i. Damaskus: Dar al-Qalam.

Al-Bayyumi, M. R. (1993). Penafsiran Konvensional Terhadap Al Qur'an. Al-Mawarid Journal of Islamic Law, 2, 18-24.

Al-Rafi'i, A. al-R. (n.d.). Batl al-Kafah al-Syahid Muhammad Farid Wajdi. Kairo: Dar al-Ma'arif.

Goldziher, I. (2015). Madzhab Tafsir Dari Klasik hingga Modern. Yogyakarta: Kalimedia.

Gusmian, I. (2003). Khazanah Tafsir di Indonesia: dari Hermeneutika hingga ideologi. Jakarta: Teraju.

Gusmian, I. (2015). Paradigma Penelitian Tafsir Al-Qur'an di Indonesia. Empirisma, 24(1), 1-10.

Mahmud, M. A. al-H. (2000). Manahij al-Mufassirin. Kairo: Dar al-Kitab al-Misri.

Mansur, M. (2004). Ma'ani' al-Qur`an Karya al-Farra'. In M. Yusup (Ed.), Studi Kitab Tafsir: Menyuarakan Teks Yang Bisu. Yogyakarta: Teras.

Mustaqim, A. (2008). Pergeseran Epistemologi Tafsir. Yogyakarta: Pustaka Pelajar.

Nirwana, D. (2010). Peta Tafsir di Mesir: Melacak Perkembangan Tafsir Al- Qur' an dari Abad Klasik Hingga Modern. Jurnal Falasifa, 1(1), 27-46.

Nugroho, M. A. (2016). Hermeneutika al-Qur'an Hasan Hanafi; Merefleksikan Teks pada Realitas Sosial dalam Konteks Kekinian. Millati: Journal of Islamic Studies and Humanities, 1(2), 187208. https://doi.org/10.18326/MLT.V1I2.187-208

Shihab, M. Q. (1994). Studi Kritis Tafsir al-manar. Bandung: Pustaka Hidayah.

Wajdi, M. F. (n.d.). al-Mushaf al-Mufassar. Cairo: Dar Sya'b.

Wajdi, M. F. (1971). Da 'irah al-Ma'arif al-Qarn al-'Isyrin (3 ed.). Beirut: Dar al-Ma'rifah. 
Khazanah Theologia, Vol. 3 No. 1 (2021): 35-54

Karakteristik Tafsir al-Mushaf al-Mufassar karya Farid Wajdi Wahyu Kusuma Aji

Halaman ini sengaja dikosongkan 